\title{
Implications of Early Pregnancy Obesity on Maternal, Fetal and Neonatal Health Retrospective cohort study from Oman
}

Anita Zutshi, ${ }^{1}{ }^{~} J a y a s r e e ~ S a n t h o s h,{ }^{1}$ Julie Sheikh, ${ }^{1}$ Fareeha Naeem, ${ }^{1}$ Ahmed Al-Hamedi, ${ }^{2}$ Shahla Khan, ${ }^{1}$ Eishthiag Al-Said ${ }^{1}$

$$
\begin{aligned}
& \text { الآثار المترتبة للبدانة في الحمل المبكر على صحة الأم و } \\
& \text { الجنين والطفل حديث الولادة } \\
& \text { دراسة استعادية بلمموعة من عمان }
\end{aligned}
$$

انيتا زوتشي، جياسري سانتوش، جولي شيخ، فريحة نعيم، أحمد الحامدي، شهلاخان، اشتياق السعيد

ABSTRACT: Objectives: This study aimed to determine the prevalence of early pregnancy obesity among Omani women and to review maternal antenatal complications, intrapartum and postpartum events and neonatal complications among such women in comparison to women of normal weight. Methods: This retrospective cohort study included 2,652 pregnant Omani women who delivered at the Royal Hospital, Muscat, Oman, between November 2011 and April 2012. The patients' electronic medical records were reviewed for antenatal, intrapartum and postpartum data. Body mass index was measured during the first trimester ( $\leq 12$ gestational weeks $)$ and classified according to the World Health Organization categories. Maternal and neonatal complications were compared between obese women and those of normal weight. Obstetric outcomes in uncomplicated pregnancies were also compared. Results: In the study cohort, there were 901 (34\%) obese women and 912 (34.4\%) women of normal weight; of these, $440(48.8 \%)$ and 672 (73.7\%) had uncomplicated pregnancies, respectively. Obese women had a significantly increased incidence of gestational diabetes (relative risk [RR]: 2.23; 95\% confidence interval [CI]: 1.70-2.92; $P<0.01$ ), gestational hypertension (RR: 3.04; 95\% CI: 1.63-5.65; $P<0.01$ ), Caesarean delivery (RR: 1.48; 95\% CI: 1.08-2.03; $P<0.01$ ), postpartum haemorrhage (RR: $2.10 ; 95 \%$ CI: $1.11-4.10 ; P=0.01$ ) and fetal macrosomia (RR: 2.71; 95\% CI: 1.21-6.09; $P<0.01$ ). Conclusion: Approximately one-third of the studied Omani women were obese. These women had a significantly increased risk of various maternal antenatal complications, intrapartum and postpartum events and neonatal complications.

Keywords: Obesity; Pregnancy; First Trimester; Pregnancy Complications; Obstetric Labor Complications; Fetal Diseases; Oman.

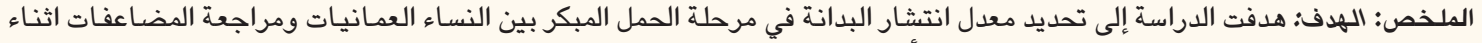

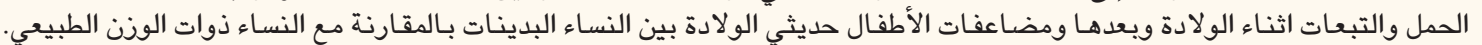

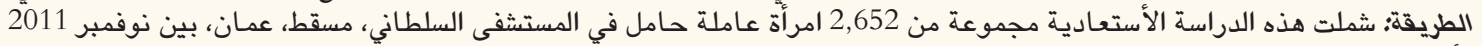

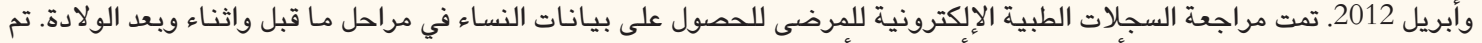

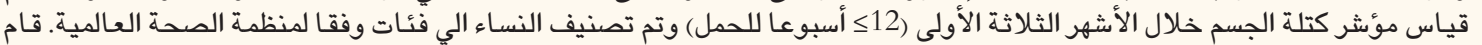

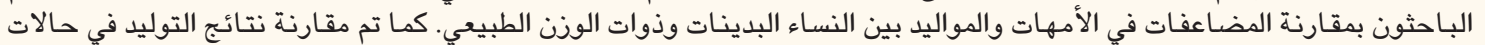

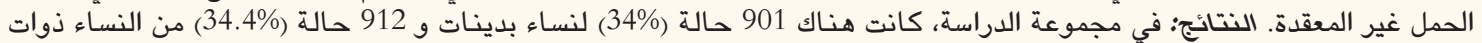

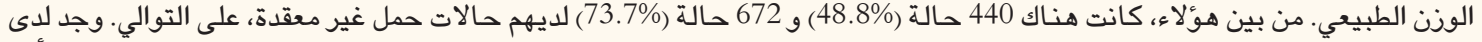

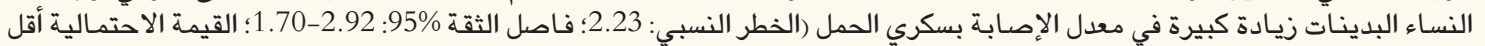

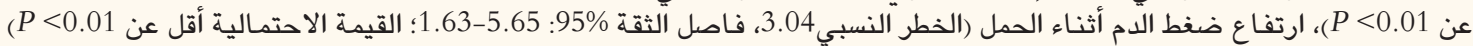

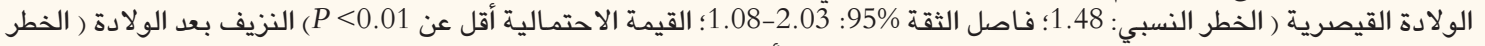

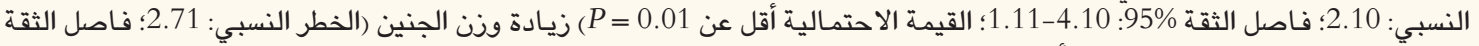

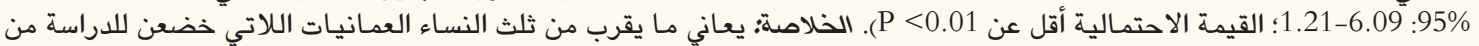

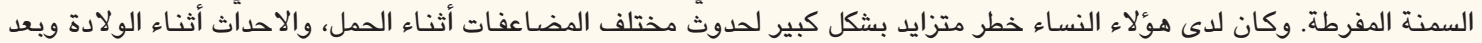

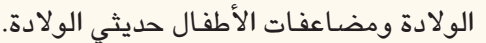

$$
\text { الكلمات المفتاحية: السمنة؛ الحمل؛ الثلث الأول للحمل؛ مضاعفات ومفات الحمل؛ مضاعفات الولادة؛ أمراض الجنين؛ عمان. }
$$

\footnotetext{
ADVANCES IN KNOWLEDGE

This study found that approximately one-third of Omani women delivering at a tertiary care hospital were obese.

Moreover, early pregnancy obesity was identified as a significant risk factor for subsequent antenatal, intrapartum and postpartum complications.
} 


\section{Application to Patient Care}

Awareness about maternal obesity and its complications may be useful to primary healthcare practitioners in Oman during the provision of preventative care and pre-pregnancy counselling services. Additionally, appropriate clinical management strategies can be planned to minimise maternal and neonatal morbidity and mortality among women with early pregnancy obesity.

$\mathrm{T}$ HE PRESENCE OF EXCESS BODY FAT CAN critically impair both health and longevity, with an increased risk of hypertension, diabetes, heart disease, stroke and cancer among obese individuals. ${ }^{1}$ Among women of reproductive age, obesity can lead to infertility; moreover, obesity in pregnancy is a recognised risk factor for many adverse maternal and neonatal outcomes, including an increased rate of Caesarean section delivery, fetal macrosomia, pre-eclampsia and gestational diabetes mellitus (GDM). ${ }^{2,3}$ Obesity has also been identified as a risk factor for maternal death. ${ }^{4}$ Moreover, obesity in early pregnancy has been associated with fetal and infant death independent of congenital anomalies and maternal pre-GDM. 5

Body mass index (BMI) is often used as a screening tool for obesity. According to the World Health Organization (WHO), individuals with a BMI of $<18.5 \mathrm{~kg} / \mathrm{m}^{2}$ are classified as underweight, those with a BMI of $18.5-24.9 \mathrm{~kg} / \mathrm{m}^{2}$ are deemed of normal weight, those with a BMI of $25.0-29.9 \mathrm{~kg} / \mathrm{m}^{2}$ are overweight/pre-obese and individuals with a BMI of $\geq 30.0 \mathrm{~kg} / \mathrm{m}^{2}$ are considered obese. ${ }^{1}$ Obesity is further classified into class I (BMI of $30-34.9 \mathrm{~kg} / \mathrm{m}^{2}$ ), class II (BMI of $35.0-39.9 \mathrm{~kg} / \mathrm{m}^{2}$ ) and class III (BMI of $\geq 40.0 \mathrm{~kg} / \mathrm{m}^{2}$ ). Individuals in the latter category are considered morbidly obese. ${ }^{1}$

Despite its inclusion in the International Classification of Diseases in 1948, obesity was not recognised as a global epidemic by the WHO until $1997 .^{6}$ Worldwide, there were more than 600 million obese adults in $2014 .^{7}$ In the Omani population, the proportion of obese adults increased from 48\% in 1991 to $51 \%$ in 2000; among women, obesity decreased slightly from $25.1 \%$ to $23.8 \%$ in the same period. ${ }^{8}$ However, there are few data from Oman addressing the issue of obesity-related morbidity among obstetric patients. Therefore, this study aimed to determine the prevalence of early pregnancy obesity among Omani women at a tertiary care hospital and to compare maternal, fetal and neonatal complications among obese women and women of normal weight.

\section{Methods}

This retrospective cohort study took place at the Royal Hospital, Muscat, Oman, between November 2011 and April 2012. All pregnant Omani women with available weight/height or BMI data at $<12$ gestational weeks who delivered at the Royal Hospital during the study period were included. In total, 3,482 deliveries occurred during this time; however, women of other nationalities ( $n=199)$, those with multiple pregnancies $(n=51)$ and women with no weight records during their first trimester $(n=580)$ were excluded from the study. Therefore, the final sample included 2,652 women. Maternal antenatal complications were compared between obese women and those of normal weight. Subsequently, the rate of intrapartum and postpartum events and neonatal complications were compared among obese and normal weight women with uncomplicated pregnancies [Figure 1].

As pre-pregnancy BMI measurements were often not available, BMI measurements during the first trimester (i.e. $\leq 12$ gestational weeks) were used to determine early pregnancy obesity, as these do not change significantly during the first three months of pregnancy. ${ }^{9}$ Antenatal complications were documented from the patients' antenatal record cards, including the incidence of GDM, hypertensive disorders of pregnancy, post-term pregnancy and induction of labour. Intrapartum and postpartum events were determined from the electronic hospital records. The intrapartum variables included the incidence of labour augmentation, meconium-stained liquor, mode of delivery and the rate of vaginal birth after a previous Caesarean section delivery. Maternal postpartum events, such as the incidence of postpartum haemorrhage and obstetric anal sphincter injuries (OASIS), along with neonatal outcomes, including perinatal mortality, congenital anomalies, birth weight and cord $\mathrm{pH}$ at delivery and neonatal intensive care unit (NICU) admission, were also compared.

The data were analysed using the Statistical Package for the Social Sciences (SPSS), Version 17 (IBM Corp., Armonk, New York, USA) and OpenEpi software (Emory University, Atlanta, Georgia, USA). Frequency distributions were calculated for each variable separately. Categorical variables were summarised as percentages while continuous variables were presented as means and standard deviations. The relative risk (RR) and 95\% confidence interval (CI) for each outcome variable was calculated. A $P$ value of $<0.05$ was deemed statistically significant.

Ethical approval for this study was obtained from the Medical Ethics \& Scientific Research Committee at the Royal Hospital (MESRC \#60). 


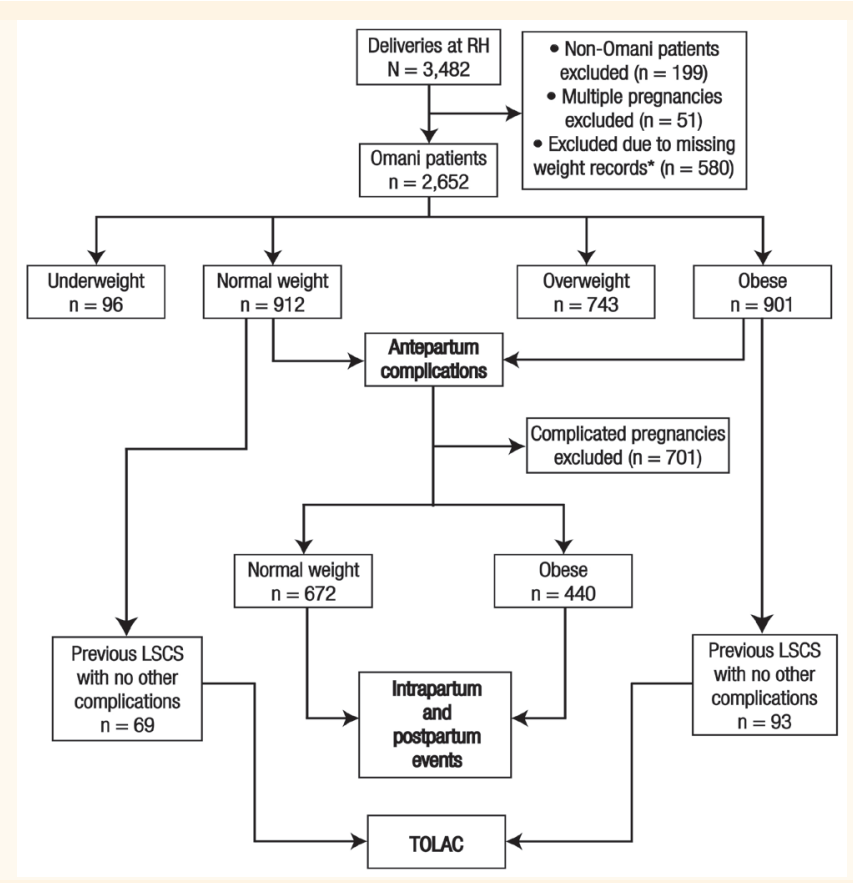

Figure 1: Diagram showing the total number of deliveries during the study period and the application of exclusion and inclusion criteria to determine the final sample used in the current study.

RH = Royal Hospital; LSCS = lower-segment Caesarean section; TOLAC = trial of labour after Caesarean section. *During the first trimester ( $\leq 12$ gestational weeks).

\section{Results}

A total of 2,652 women were included in the study. Of these, 901 (34\%) were obese, 96 (3.6\%) were underweight, 912 (34.4\%) were of normal weight and 743 (28\%) were overweight. Among the obese women, 549 (60.9\%) were class I, 225 (25\%) were class II and 127 (14.1\%) were class III. Obesity was more common with increased age and parity [Figure 2]. With regards to maternal antenatal complications, obese women had a significantly increased risk of GDM (RR: 2.23; 95\% CI: $1.70-2.92 ; P<0.01)$ and gestational hypertension (RR: 3.04; 95\% CI: 1.63-5.65; $P<0.01$ ). However, the incidence of preterm labour, post-term pregnancy and induction of labour were comparable among obese women and those of normal weight [Table 1]. A total of 440 obese (48.8\%) and 672 normal weight (73.7\%) women had uncomplicated pregnancies.

Intrapartum and postpartum events were compared among the women with uncomplicated pregnancies. There were no statistically significant differences in the incidence of continuous intrapartum monitoring, fetal scalp electrode placement, prolonged labour, labour augmentation or meconium-stained liquor between the groups. Obese women had a significantly higher incidence of intrapartum hypertension (RR: 2.40; 95\% CI: 1.24-4.46; $P<0.01$ ). Postpartum hypertension was six times more common among obese women than women of normal weight (RR: 6.11; 95\% CI: 0.69-54.47; $P=0.04$ ). There was a significant
A
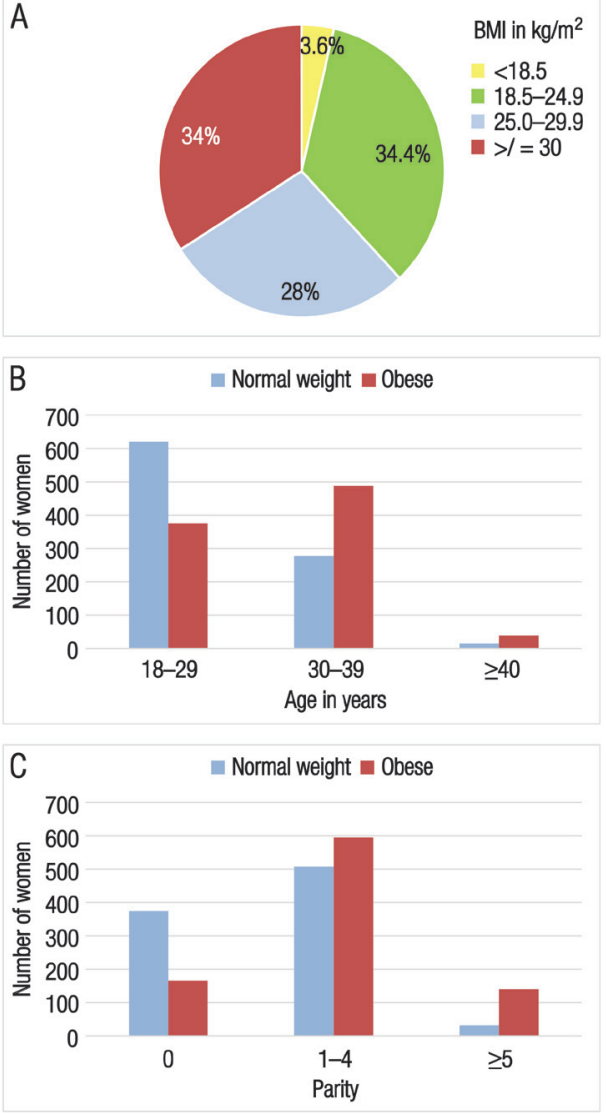

Figure 2: Distribution according to (A) body mass index, (B) age and (C) parity of pregnant Omani women delivering at the Royal Hospital, Muscat, Oman $(\mathrm{N}=2,652)$. $B M I=$ body mass index. 
Table 1: Maternal antenatal complications among pregnant Omani women delivering at the Royal Hospital, Muscat, Oman $(\mathrm{N}=2,652)$

\begin{tabular}{|c|c|c|c|c|}
\hline \multirow[t]{2}{*}{ Complication } & \multicolumn{2}{|c|}{$\begin{array}{c}\text { n } \\
(\%)\end{array}$} & \multirow[t]{2}{*}{$\begin{array}{c}\mathrm{RR} \\
(95 \% \mathrm{CI})\end{array}$} & \multirow[t]{2}{*}{$\begin{array}{c}P \\
\text { value }\end{array}$} \\
\hline & $\begin{array}{c}\text { Normal } \\
\text { weight } \\
\text { women } \\
(\mathrm{n}=912)\end{array}$ & $\begin{array}{c}\text { Obese } \\
\text { women } \\
(\mathrm{n}=901)\end{array}$ & & \\
\hline GDM & $\begin{array}{c}69 \\
(7.6)\end{array}$ & $\begin{array}{c}152 \\
(16.9)\end{array}$ & $\begin{array}{c}2.23 \\
(1.70-2.92)\end{array}$ & $<0.01$ \\
\hline GHTN & $\begin{array}{c}13 \\
(1.4)\end{array}$ & $\begin{array}{c}39 \\
(4.3)\end{array}$ & $\begin{array}{c}3.04 \\
(1.63-5.65)\end{array}$ & $<0.01$ \\
\hline Pre-eclampsia & $\begin{array}{c}5 \\
(0.5)\end{array}$ & $\begin{array}{c}8 \\
(0.9)\end{array}$ & $\begin{array}{c}1.62 \\
(0.53-4.93)\end{array}$ & 0.21 \\
\hline $\begin{array}{l}\text { Preterm } \\
\text { labour }\end{array}$ & $\begin{array}{c}43 \\
(4.7)\end{array}$ & $\begin{array}{c}41 \\
(4.6)\end{array}$ & $\begin{array}{c}0.97 \\
(0.64-1.47)\end{array}$ & 0.43 \\
\hline $\begin{array}{l}\text { Post-term } \\
\text { pregnancy }\end{array}$ & $\begin{array}{c}189 \\
(20.7)\end{array}$ & $\begin{array}{c}154 \\
(17.1)\end{array}$ & $\begin{array}{c}0.82 \\
(0.68-1.00)\end{array}$ & 0.02 \\
\hline $\begin{array}{l}\text { Induction of } \\
\text { labour }\end{array}$ & $\begin{array}{l}73 \\
(8)\end{array}$ & $\begin{array}{c}67 \\
(7.4)\end{array}$ & $\begin{array}{c}0.93 \\
(0.68-1.28)\end{array}$ & 0.32 \\
\hline Eclampsia & $\begin{array}{c}2 \\
(0.2)\end{array}$ & $\begin{array}{c}2 \\
(0.2)\end{array}$ & $\begin{array}{c}1.01 \\
(0.14-7.17)\end{array}$ & 0.49 \\
\hline
\end{tabular}

$R R=$ relative risk; $C I=$ confidence interval; $G D M=$ gestational diabetes mellitus; GHTN = gestational hypertension.

increase in the risk of postpartum haemorrhage among obese women (RR: 2.10; 95\% CI: $1.11-4.10 ; P=0.01$ ). Obese women had significantly lower episiotomy rates (RR: 0.63; 95\% CI: 0.52-0.77; $P<0.01$ ). Among women with vaginal deliveries, no statistically significant incidence in OASIS was noted between the groups ( $0.2 \%$ versus $0.5 \%$ among normal weight and obese women, respectively; $P=0.19$ ). The incidence of instrumental delivery in the obese group was half that of the normal weight group (RR: $0.52 ; 95 \% \mathrm{CI}$ : 0.29-1.00; $P=0.02$ ). Obese women were 1.4-times more likely to have a lower-segment Caesarean section (LSCS) delivery than women of normal weight (RR: 1.48; 95\% CI: 1.08-2.03; $P<0.01$ ) [Table 2].

The most common indications for LSCS deliveries in both groups were pathological fetal heart tracing and nonprogressive labour. The mean estimated blood loss was greater in obese women, irrespective of mode of delivery [Table 3]. Among those who had an LSCS delivery, mean hospital stay duration was longer for obese women than normal weight women $(4.11 \pm 1.60$ days versus $3.62 \pm 1.08$ days). In terms of neonatal outcomes, there was no difference in the rates of perinatal mortality, NICU admission or low cord $\mathrm{pH}$ at birth between the obese and normal weight groups. The incidence of congenital anomalies was higher among obese women, although this was not statistically significant (RR: 1.36; 95\% CI: 0.70-2.63; $P=0.18$ ). However, obese women had a significantly lower incidence of low-birth-weight babies (RR: 0.57; 95\% CI:
Table 2: Maternal intrapartum and postpartum events among pregnant Omani women delivering at the Royal Hospital, Muscat, Oman $(\mathrm{N}=2,652)$

\begin{tabular}{|c|c|c|c|c|}
\hline & \multicolumn{2}{|c|}{$\begin{array}{c}\mathrm{n} \\
(\%)\end{array}$} & \multirow[t]{2}{*}{$\begin{array}{c}\text { RR } \\
(95 \% \mathrm{CI})\end{array}$} & \multirow[t]{2}{*}{$P$ value } \\
\hline & $\begin{array}{c}\text { Normal } \\
\text { weight } \\
\text { women* } \\
(\mathrm{n}=672)\end{array}$ & $\begin{array}{c}\text { Obese } \\
\text { women** } \\
(n=440)\end{array}$ & & \\
\hline \multicolumn{5}{|l|}{ Event } \\
\hline $\begin{array}{l}\text { Continuous } \\
\text { fetal } \\
\text { monitoring }\end{array}$ & $\begin{array}{c}198 \\
(29.5)\end{array}$ & $\begin{array}{l}145 \\
(33)\end{array}$ & $\begin{array}{c}1.12 \\
(0.94-1.34)\end{array}$ & 0.11 \\
\hline $\begin{array}{l}\text { Fetal scalp } \\
\text { electrode } \\
\text { placement }\end{array}$ & $\begin{array}{c}59 \\
(8.8)\end{array}$ & $\begin{array}{c}43 \\
(9.8)\end{array}$ & $\begin{array}{c}1.11 \\
(0.77-1.62)\end{array}$ & 0.29 \\
\hline $\begin{array}{l}\text { Slow/ } \\
\text { prolonged } \\
\text { stage I labour }\end{array}$ & $\begin{array}{c}70 \\
(10.4)\end{array}$ & $\begin{array}{c}52 \\
(11.8)\end{array}$ & $\begin{array}{c}1.14 \\
(0.81-1.59)\end{array}$ & 0.23 \\
\hline $\begin{array}{l}\text { Slow/ } \\
\text { prolonged } \\
\text { stage II labour }\end{array}$ & $\begin{array}{l}18 \\
(2.7)\end{array}$ & $\begin{array}{c}8 \\
(1.8)\end{array}$ & $\begin{array}{c}0.68 \\
(0.30-1.55)\end{array}$ & 0.18 \\
\hline $\begin{array}{l}\text { Labour } \\
\text { augmentation }\end{array}$ & $\begin{array}{c}99 \\
(14.7)\end{array}$ & $\begin{array}{c}61 \\
(13.9)\end{array}$ & $\begin{array}{c}0.94 \\
(0.70-1.27)\end{array}$ & 0.35 \\
\hline $\begin{array}{l}\text { Meconium- } \\
\text { stained liquor }\end{array}$ & $\begin{array}{l}61 \\
(9.1)\end{array}$ & $\begin{array}{c}41 \\
(9.3)\end{array}$ & $\begin{array}{c}1.13 \\
(0.77-1.63)\end{array}$ & 0.28 \\
\hline $\begin{array}{l}\text { Intrapartum } \\
\text { HTN }\end{array}$ & $\begin{array}{c}14 \\
(2.1)\end{array}$ & $\begin{array}{l}22 \\
(5)\end{array}$ & $\begin{array}{c}2.40 \\
(1.24-4.46)\end{array}$ & $<0.01$ \\
\hline $\begin{array}{l}\text { Postpartum } \\
\text { haemorrhage }\end{array}$ & $\begin{array}{c}15 \\
(2.2)\end{array}$ & $\begin{array}{c}21 \\
(4.8)\end{array}$ & $\begin{array}{c}2.10 \\
(1.11-4.10)\end{array}$ & 0.01 \\
\hline $\begin{array}{l}\text { Postpartum } \\
\text { HTN }\end{array}$ & $\begin{array}{c}1 \\
(0.2)\end{array}$ & $\begin{array}{c}4 \\
(0.9)\end{array}$ & $\begin{array}{c}6.11 \\
(0.69-54.47)\end{array}$ & 0.04 \\
\hline \multicolumn{5}{|c|}{ Mode of delivery } \\
\hline SVD & $\begin{array}{c}566 \\
(84.2)\end{array}$ & $\begin{array}{l}361 \\
(82)\end{array}$ & $\begin{array}{c}0.97 \\
(0.92-1.03)\end{array}$ & 0.17 \\
\hline $\begin{array}{l}\text { Instrumental } \\
\text { delivery }\end{array}$ & $\begin{array}{l}38 \\
(5.7)\end{array}$ & $\begin{array}{l}13 \\
(3)\end{array}$ & $\begin{array}{c}0.52 \\
(0.29-1.00)\end{array}$ & 0.02 \\
\hline LSCS & $\begin{array}{c}68 \\
(10.1)\end{array}$ & $\begin{array}{c}66 \\
(15)\end{array}$ & $\begin{array}{c}1.48 \\
(1.08-2.03)\end{array}$ & $<0.01$ \\
\hline Episiotomy $^{\dagger}$ & $\begin{array}{c}241 \\
(39.9)\end{array}$ & $\begin{array}{c}94 \\
(25.1)\end{array}$ & $\begin{array}{c}0.63 \\
(0.52-0.77)\end{array}$ & $<0.01$ \\
\hline OASIS $^{\dagger}$ & $\begin{array}{c}1 \\
(0.2)\end{array}$ & $\begin{array}{c}2 \\
(0.5)\end{array}$ & $\begin{array}{c}3.22 \\
(0.29-35.50)\end{array}$ & 0.19 \\
\hline
\end{tabular}

$R R=$ relative risk; $C I=$ confidence interval; $H T N=$ hypertension; $S V D=$ spontaneous vaginal delivery LSCS = lower-segment Caesarean section; OASIS = obstetric anal sphincter injuries.

"Including only those with uncomplicated pregnancies. ${ }^{\dagger}$ The total dataset for this variable was 604 for women of normal weight and 374 for obese women.

$0.37-0.88 ; P<0.01)$ and a 2.7 -times increased likelihood of fetal macrosomia (RR: 2.71; 95\% CI: 1.21-6.09; $P<0.01$ ) [Table 4].

Among women with at least one previous LSCS delivery, obese women were more likely to have a failed trial of labour and a repeat Caesarean section delivery (RR: 1.37; 95\% CI: 0.88-2.14; $P=0.07$ ). Morbidly obese women also had a significantly higher rate of repeat LSCS delivery (RR: 2.30; 95\% CI: 1.33-3.96; $P<0.01$ ). 
Table 3: Blood loss and hospital stay according to mode of delivery among pregnant Omani women delivering at the Royal Hospital, Muscat, Oman $(\mathrm{N}=2,652)$

\begin{tabular}{|c|c|c|c|c|c|c|}
\hline \multirow[t]{2}{*}{$\begin{array}{l}\text { Mode of } \\
\text { delivery }\end{array}$} & \multicolumn{3}{|c|}{$\begin{array}{l}\text { Normal weight women } \\
\qquad(\mathrm{n}=672)\end{array}$} & \multicolumn{3}{|c|}{$\begin{array}{l}\text { Obese women } \\
\qquad(n=440)\end{array}$} \\
\hline & n (\%) & $\begin{array}{c}\text { Mean blood } \\
\text { loss in } \mathrm{mL} \pm \mathrm{SD}\end{array}$ & $\begin{array}{c}\text { Mean hospital } \\
\text { stay in days } \\
\pm \text { SD }\end{array}$ & n (\%) & $\begin{array}{c}\text { Mean blood } \\
\text { loss in } \mathrm{mL} \pm \mathrm{SD}\end{array}$ & $\begin{array}{c}\text { Mean hospital } \\
\text { stay in days } \\
\pm \text { SD }\end{array}$ \\
\hline SVD & $566(84.2)$ & $169.53 \pm 71.27$ & $2.00 \pm 1.07$ & $361(82)$ & $195.91 \pm 165.30$ & $2.04 \pm 1.20$ \\
\hline $\begin{array}{l}\text { Instrumental } \\
\text { delivery }\end{array}$ & $38(5.7)$ & $207.57 \pm 119.25$ & $3.08 \pm 2.70$ & $13(3)$ & $269.23 \pm 288.34$ & $3.00 \pm 1.38$ \\
\hline LSCS & $68(10.1)$ & $419.11 \pm 135.77$ & $3.62 \pm 1.08$ & $66(15)$ & $538.27 \pm 257.00$ & $4.11 \pm 1.60$ \\
\hline
\end{tabular}

SD = standard deviation; $S V D=$ spontaneous vaginal delivery; LSCS = lower-segment Caesarean section .

* Including only those with uncomplicated pregnancies.

Table 4: Neonatal outcomes among obese and normal weight pregnant Omani women delivering at the Royal Hospital, Muscat, Oman $(\mathrm{N}=2,652)$

\begin{tabular}{|c|c|c|c|c|}
\hline \multirow[t]{2}{*}{ Outcome } & \multicolumn{2}{|c|}{$\begin{array}{c}\mathrm{n} \\
(\%)\end{array}$} & \multirow[t]{2}{*}{$\begin{array}{c}\text { RR } \\
(95 \% \mathrm{CI})\end{array}$} & \multirow[t]{2}{*}{$\begin{array}{c}P \\
\text { value }\end{array}$} \\
\hline & $\begin{array}{c}\text { Normal } \\
\text { weight } \\
\text { women* }^{*}(n=672)\end{array}$ & $\begin{array}{c}\text { Obese } \\
\text { women" } \\
(\mathrm{n}=440)\end{array}$ & & \\
\hline $\begin{array}{l}\text { Perinatal } \\
\text { mortality }\end{array}$ & $\begin{array}{c}8 \\
(1.2)\end{array}$ & $\begin{array}{c}3 \\
(0.7)\end{array}$ & $\begin{array}{c}0.57 \\
(0.15-2.15)\end{array}$ & 0.21 \\
\hline $\begin{array}{l}\text { Congenital } \\
\text { anomalies }\end{array}$ & $\begin{array}{c}18 \\
(2.7)\end{array}$ & $\begin{array}{c}16 \\
(3.6)\end{array}$ & $\begin{array}{c}1.36 \\
(0.70-2.63)\end{array}$ & 0.18 \\
\hline $\begin{array}{l}\text { Birth weight } \\
\text { of }<2,500 \mathrm{~g}\end{array}$ & $\begin{array}{c}72 \\
(10.7)\end{array}$ & $\begin{array}{c}27 \\
(6.1)\end{array}$ & $\begin{array}{c}0.57 \\
(0.37-0.88)\end{array}$ & $<0.01$ \\
\hline $\begin{array}{l}\text { Birth weight } \\
\text { of }>4,000 \mathrm{~g}\end{array}$ & $\stackrel{9}{(1.3)}$ & $\begin{array}{c}16 \\
(3.6)\end{array}$ & $\begin{array}{c}2.71 \\
(1.21-6.09)\end{array}$ & $<0.01$ \\
\hline $\begin{array}{l}\text { Cord } \mathrm{pH} \text { of } \\
<7.2\end{array}$ & $\begin{array}{l}16 \\
(2.4)\end{array}$ & $\begin{array}{c}8 \\
(1.8)\end{array}$ & $\begin{array}{c}0.76 \\
(0.33-1.77)\end{array}$ & 0.27 \\
\hline $\begin{array}{l}\text { NICU } \\
\text { admission }\end{array}$ & $\begin{array}{l}54 \\
(8)\end{array}$ & $\begin{array}{l}31 \\
(7)\end{array}$ & $\begin{array}{c}0.88 \\
(0.57-1.34)\end{array}$ & 0.27 \\
\hline
\end{tabular}

$R R=$ relative risk; $C I=$ confidence interval; $N I C U=$ neonatal intensive care unit.

Among the obese women, one patient had a scar rupture and another had an urgent evacuation due to a wound haematoma. There were no cases of maternal mortality in the study cohort.

\section{Discussion}

In general, women tend to gain weight as age and parity increases..$^{10}$ Due to the association between obesity and hyperlipidaemia, hyperinsulinaemia and insulin resistance, obese pregnant women are more likely to develop pre-eclampsia and GDM. ${ }^{11}$ In the current study, obese women had a two-fold increase in GDM and a three-fold increase in gestational hypertension. In a meta-analysis of 20 studies, Chu et al. suggested that the risk of developing GDM increases with obesity, with an odds ratio (OR) of 2.14, 3.56 and 8.56 for overweight, obese and morbidly obese women, respectively. ${ }^{12}$ Similar observations have been previously noted in Oman..$^{13}$ A prospective study in Saudi Arabia also reported an increased risk of GDM and pre-eclampsia with obesity. ${ }^{14}$ In a large populationbased 15-year cohort study, obese women showed an increased risk of pregnancy-induced hypertension, with an adjusted OR of 2.38 and 3.00 for moderate and severe obesity, respectively. ${ }^{15}$

McDonald et al. conducted a systematic review and meta-analysis of 84 studies (including 64 cohort and 20 case-control studies) on 1,095,834 women; the authors concluded that obese women had a higher risk of preterm delivery (OR: 1.24; 95\% CI: 1.13-1.27). ${ }^{16}$ A Danish National Birth Cohort study reported that being overweight or obese before pregnancy increased the risk of preterm premature rupture of the membranes. ${ }^{17}$ Usha Kiran et al. reported that obese pregnant women were more likely to undergo induction of labour (OR: 1.6; 95\% CI: 1.3-1.9), while Ray et al. observed that morbidly obese women were significantly more likely to require invasive fetal (27\% versus $0 \% ; P<0.001)$ and uterine contraction $(30 \%$ versus $0 \%$; $P<0.001)$ monitoring. ${ }^{18,19}$ In addition, the overall duration of labour has been reported to be longer in obese women, with slower progression of the early first stage of labour. ${ }^{20}$ However, such associations were not observed in the current study. It has been postulated that obesity may impair the ability of the uterus to contract in labour. ${ }^{21}$ In agreement with the findings of the present study, Sebire et al. reported a higher incidence of postpartum haemorrhage in overweight (OR: 1.16; 95\% CI: 1.12-1.21) and obese (OR: 1.39; 95\% CI: $1.32-1.46)$ women. ${ }^{22}$ Another study indicated an unadjusted OR of 2.37 (95\% CI: 2.01-2.79) for postpartum haemorrhage in obese women. ${ }^{23}$

Obesity may be protective against third- and fourth-degree perineal lacerations, independent of parity, race, birth weight and mode of delivery. ${ }^{24}$ In the current study, the obese cohort had a significantly lower episiotomy rate, with a non-significant increase in 
OASIS among obese women. Overall, obese women were significantly more likely to have a Caesarean delivery; this finding has been reflected in previous studies reporting ORs of 2-2.9. ${ }^{25,26}$ During a Caesarean section procedure, obese women face a greater risk of anaesthetic complications, technical difficulties during the surgery, increased blood loss, wound infection and deep vein thrombosis. ${ }^{3}$ In the current study, only one obese woman with a history of previous LSCS deliveries suffered a wound haematoma and none of the women experienced deep vein thrombosis. Such reduced morbidity rates may be due to the fact that the study was conducted in a tertiary care centre with strict intrapartum monitoring protocols and a greater availability of senior obstetricians. However, such findings may also be due to the size of the cohort. Antepartum monitoring, administration of timely thromboprophylaxis and intra- and postpartum management with input from senior obstetricians and anaesthesiologists are recommended to aid in reducing complications in these high-risk pregnancies.

The instrumental delivery rate for obese women was almost half that of the normal weight women included in the present study. The apparent reluctance among obstetricians to proceed with instrumental delivery in obese women could be due to expected errors in fetal weight estimation and the increased risk of shoulder dystocia. The instrumental delivery rate in singleton deliveries among obese women has been reported to be $7.6 \%$ compared to $12.2 \%$ in a general maternity unit. ${ }^{27}$ Regardless of the mode of delivery, longer post-delivery hospital stays have been reported among obese women compared to women of normal weight (14.3\% versus 4.7\%; OR: 1.42; 95\% CI: $1.07-1.89){ }^{28}$ In the current study, mean hospital stays were longer only for those obese women who underwent an LSCS delivery. No significant differences were found in the rates of perinatal mortality, cord $\mathrm{pH}$, NICU admission or congenital abnormalities among neonates of obese women. Indeed, rates of low cord pH, low Apgar scores and shoulder dystocia have been reported as similar for women of all BMI categories. ${ }^{29,30}$

In the current study, obese mothers had a 2.7times higher incidence of fetal macrosomia (i.e. babies with a birth weight of $>4,000 \mathrm{~g}$ ). For birth weights above the $90^{\text {th }}$ centile, Zhang et al. reported the RR to be 1.57 (95\% CI: 1.50-1.64) and 2.36 (95\% CI: 2.23-2.50) for overweight and obese mothers, respectively. ${ }^{21}$ In the present study, the risk of having a low-birth-weight baby for obese women was half that of normal weight women. In their systematic review and meta-analysis, McDonald et al. also reported that the overall risk of having an infant with low birth weight was lower in overweight and obese women. ${ }^{16}$
In the current study, both obese and morbidly obese women with a history of previous Caesarean section deliveries had a significantly higher rate of repeat LSCS deliveries. This observation is supported by previous research..$^{31,32}$

The implementation of national guidelines for early pregnancy obesity at local health centres in Oman is recommended to facilitate appropriate interventions and encourage the timely referral of obese mothers to specialist services to ensure safe outcomes. Community healthcare providers should identify obesity among young women in order to recommend pre-pregnancy counselling and weight reduction strategies. Moreover, obesity education and dietary counselling should be included in adolescent health programmes as a method of primary obesity prevention.

\section{Conclusion}

Overall, approximately one-third of the Omani pregnant women in the current study were obese. Obesity was significantly associated with GDM, gestational hypertension, intrapartum and postpartum hypertension, postpartum haemorrhage, instrumental delivery, LSCS, episiotomies, low birth weight and fetal macrosomia.

\section{CONFLICT OF INTEREST}

The authors declare no conflicts of interest.

\section{FUNDING}

No funding was received for this study.

\section{References}

1. World Health Organization. Obesity: Preventing and managing the global epidemic. From: www.who.int/nutrition/publications/ obesity/WHO_TRS_894/en/ Accessed: Jan 2018.

2. NHLBI Education Initiative Expert Panel on the Identification, Evaluation, and Treatment of Obesity in Adults. Clinical guidelines on the identification, evaluation and treatment of overweight and obesity in adults: The evidence report. From: www. ncbi.nlm.nih.gov/books/NBK2003/ Accessed: Jan 2018.

3. Center for Maternal and Child Enquiries, Royal College of Obstetricians and Gynaecologists. CMACE/RCOG joint guideline: Management of women with obesity in pregnancy. From: www. rcog.org.uk/globalassets/documents/guidelines/cmacercogj ointguidelinemanagementwomenobesitypregnancya.pdf Accessed: Jan 2018.

4. Confidential Enquiry into Maternal and Child Health. Saving mothers' lives: Reviewing maternal deaths to make motherhood safer. From: www.publichealth.hscni.net/sites/default/fil es/Saving\%20Mothers\%27\%20Lives\%202003-05\%20.pdf Accessed: Jan 2018.

5. Tennant PW, Rankin J, Bell R. Maternal body mass index and the risk of fetal and infant death: a cohort study from the North of England. Hum Reprod 2011; 26:1501-11. doi: 10.1093/humrep/ der052. 
6. James WP. WHO recognition of the global obesity epidemic. Int J Obes (Lond) 2008; 32:S120-6. doi: 10.1038/ijo.2008.247.

7. World Health Organization. Obesity and overweight. From: www.who.int/mediacentre/factsheets/fs311/en/\#content Accessed: Jan 2018.

8. Al-Lawati JA, Jousilahti PJ. Prevalence and 10-year secular trend of obesity in Oman. Saudi Med J 2004; 25:346-51

9. Natamba BK, Sanchez SE, Gelaye B, Williams MA. Concordance between self-reported pre-pregnancy body mass index (BMI) and BMI measured at the first prenatal study contact. BMC Pregnancy Childbirth 2016; 16:187. doi: 10.1186/s12884-0160983-z.

10. Gupta S, Kapoor S. Independent and combined association of parity and short pregnancy with obesity and weight change among Indian women. Health 2012; 4:271-6. doi: 10.4236/hea lth.2012.45044.

11. Catalano PM. Obesity, insulin resistance, and pregnancy outcome. Reproduction 2010; 140:365-71. doi: 10.1530/REP-10-0088.

12. Chu SY, Callaghan WM, Kim SY, Schmid CH, Lau J, England LJ, et al. Maternal obesity and risk of gestational diabetes mellitus. Diabetes Care 2007; 30:2070-6. doi: 10.2337/dc06-2559a.

13. Al-Hakmani FM, Al-Fadhil FA, Al-Balushi LH, Al-Harthy NA, Al-Bahri ZA, Al-Rawahi NA, et al. The effect of obesity on pregnancy and its outcome in the population of Oman, Seeb Province. Oman Med J 2016; 31:12-17. doi: 10.5001/omj.2016.03.

14. El-Gilany AH, Hammad S. Body mass index and obstetric outcomes in pregnant in Saudi Arabia: A prospective cohort study. Ann Saudi Med 2010; 30:376-80. doi: 10.4103/0256-4947.67075.

15. Robinson HE, O'Connell CM, Joseph KS, McLeod NL. Maternal outcomes in pregnancies complicated by obesity. Obstet Gynecol 2005; 106:1357-64. doi: 10.1097/01.AOG.0000188387.88032.41.

16. McDonald SD, Han Z, Mulla S, Beyene J; Knowledge Synthesis Group. Overweight and obesity in mothers and risk of preterm birth and low birth weight infants: Systematic review and metaanalyses. BMJ 2010; 341:c3428. doi: 10.1136/bmj.c3428.

17. Nohr EA, Bech BH, Vaeth M, Rasmussen KM, Henriksen TB, Olsen J. Obesity, gestational weight gain and preterm birth: A study within the Danish National Birth Cohort. Paediatr Perinat Epidemiol 2007; 21:5-14. doi: 10.1111/j.1365-3016.2007.00762.x.

18. Usha Kiran TS, Hemmadi S, Bethel J, Evans J. Outcome of pregnancy in a woman with an increased body mass index. BJOG 2005; 112:768-72. doi: 10.1111/j.1471-0528.2004.00546.x.

19. Ray A, Hildreth A, Esen UI. Morbid obesity and intra-partum care. J Obstet Gynaecol 2008; 28:301-4. doi: 10.1080/0144361 0802042548 .

20. Norman SM, Tuuli MG, Odibo AO, Caughey AB, Roehl KA, Cahill AG. The effects of obesity on the first stage of labor Obstet Gynecol 2012; 120:130-5. doi: 10.1097/AOG.0b013e31 $8259589 \mathrm{c}$
21. Zhang J, Bricker L, Wray S, Quenby S. Poor uterine contractility in obese women. BJOG 2007; 114:343-8. doi: 10.1111/ j.1471-0528.2006.01233.x.

22. Sebire NJ, Jolly M, Harris JP, Wadsworth J, Joffe M, Beard RW, et al. Maternal obesity and pregnancy outcome: A study of 287,213 pregnancies in London. Int J Obes Relat Metab Disord 2001; 25:1175-82. doi: $10.1038 /$ sj.ijo.0801670.

23. Fyfe EM, Thompson JM, Anderson NH, Groom KM, McCowan LM. Maternal obesity and postpartum haemorrhage after vaginal and caesarean delivery among nulliparous women at term: A retrospective cohort study. BMC Pregnancy Childbirth 2012; 12:112. doi: 10.1186/1471-2393-12-112.

24. Garretto D, Lin BB, Syn HL, Judge N, Beckerman K, Atallah F, et al. Obesity may be protective against severe perineal lacerations. J Obes 2016; 2016:9376592. doi: 10.1155/2016/9376592.

25. Kaiser PS, Kirby RS. Obesity as a risk factor for cesarean in a lowrisk population. Obstet Gynaecol 2001; 97:39-43. doi: 10.1016/ S0029-7844(00)01078-4.

26. Machado LS. Cesarean section in morbidly obese parturients: Practical implications and complications. N Am J Med Sci 2012; 4:13-18. doi: 10.4103/1947-2714.92895.

27. Edwards L, Lim BH. Challenges of intrapartum care in obese women. In: Mahmood TA, Arulkumaran S, Eds. Obesity: A ticking time bomb for reproductive health, 1st ed. Amsterdam, Netherlands: Elsevier, 2012. Pp. 325-37.

28. Arabin B, Stupin JH. Overweight and obesity before, during and after pregnancy: Part 2 - Evidence-based risk factors and interventions. Geburtshilfe Frauenheilkd 2014; 74:646-55. doi: $10.1055 / \mathrm{s}-0034-1368462$.

29. Arrowsmith S, Wray S, Quenby S. Maternal obesity and labour complications following induction of labour in prolonged pregnancy. BJOG 2011; 118:578-88. doi: 10.1111/j.1471-0528.2010. 02889.x.

30. Vinturache AE, McDonald S, Slater D, Tough S. Perinatal outcomes of maternal overweight and obesity in term infants: A population-based cohort study in Canada. Sci Rep 2015; 5:9334. doi: 10.1038/srep09334.

31. Durnwald CP, Ehrenberg HM, Mercer BM. The impact of maternal obesity and weight gain on vaginal birth after cesarean section success. Am J Obstet Gynecol 2004; 191:954-7. doi: 10.10 16/j.ajog.2004.05.051

32. The Royal Australian and New Zealand College of Obstetricians and Gynaecologists. Birth after previous caesarean section. From: www.ranzcog.edu.au/RANZCOG_SITE/media/RANZC OG-MEDIA/Women's\%20Health/Statement\%20and\%20 guidelines/Clinical-Obstetrics/Birth-after-previousCaesarean-Section-(C-Obs-38)-Re-write-July-2015.pdf? ext=.pdf Accessed: Jan 2018. 